\title{
PHYSICAL ACTIVITY, PHYSICAL FITNESS AND ACADEMIC ACHIEVEMENTS OF PRIMARY SCHOOL CHILDREN
}

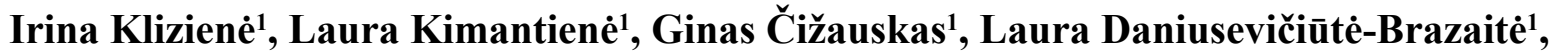 \\ Gintautas Cibulskas ${ }^{1}$, Arūnè Janulevičiene் ${ }^{2}$ \\ Kaunas University of Technology ${ }^{1}$, Kaunas, Lithuania \\ Kaunas "Vyturys" Gymnasium², Kaunas, Lithuania
}

\begin{abstract}
Background.The purpose of this study is to estimate physical activity, physical fitness and assessment of mathematical achievements in primary schoolchildren.

Methods. The study involved 1 st grade students $(N=93), 45$ of which were girls and 48 were boys. The flexibility test, the long jump test, $3 \times 10 \mathrm{~m}$ speed shuttle run test, a medical (stuffed) $1 \mathrm{~kg}$ ball pushing from the chest test were used. Physical activity was measured using Children's Physical Activity Questionnaire. Academic achievements were assessed using Mathematical diagnostic progress tests and mathematical learning achievements according to curriculum content.

Results. It turned out that both boys (95.87 MET/min/week) and girls (91.30 MET / min/ week) were physically active in physical education lessons $(\mathrm{p}>0.05)$. Long jump results ranged from $105.2 \mathrm{~cm}$ (girls) to $118.3 \mathrm{~cm}$ (boys), statistically significant differences were detected $(\mathrm{p}<0.05)$ The best score of the girls' shuttle running $3 \times 10 \mathrm{~m}$ was $9.55 \mathrm{~s}$, for boys it was $9.2 \mathrm{~s}$, the worst performance time for boys was $13.68 \mathrm{~s}$, for girls $-13.54 \mathrm{~s}(p<.05)$. Mathematics Diagnostic Progress Tests for both girls and boys indicated satisfactory levels.

Conclusion. We should note that all 4 fitness tests had a positive, linear association with physical fitness tests and mathematics test scores.
\end{abstract}

Keywords: physical activity, physical fitness, mathematical achievements, academic achievements, primary education.

\section{INTRODUCTION}

$\mathrm{T}$ The observed magnitude of the relation between physical activity and health varies considerably, especially in children (Rowlands, Ingledew, \& Eston, 2000). However, an active lifestyle contributes significantly to health and the prevention of diseases (Janssen \& LeBlanc., 2010) and has been further linked to an adequate development of motor and cognitive functions (Erickson, Hillman, \& Kramer, 2015). The application of PA at schools is very important; primary school can increase the physical activity of children from moderate to intensive, for example, time of the breaks (Powell et al., 2016). Low PA and long sitting, for example, in lessons, as well as immobility during breaks lead to poorer learning achievements in children (Syväoja et al., 2013). Children who have increased PA levels from moderate to severe before 11 years of age achieve better learning outcomes at the age of 11,13 and 16 (Booth et al., 2014). This indicates that PA in primary classes is a very important factor. Physical activity (PA) researchers have often proposed the necessity of school-affiliated PA, suggesting that the time spent in PA would benefit health and might contribute to academic performance. Especially in children cognitive functions seem to benefit from 
physical activity (PA), with their highly plastic brains as one possible explanation (Tomporowski, Davis, Miller, \& Naglieri, 2008). As a key aspect of cognitive functioning, working memory reflects the ability to hold and manipulate information to regulate thoughts and behaviour (Diamond, 2013). Therefore working memory is a crucial cognitive aspect in children for success at school.

The purpose of this study was to estimate physical activity, physical fitness and mathematical achievements in primary schoolchildren.

\section{METHODS}

Participants. According to the SVIS data base statistics (http://www.svis.smm.lt/), the number of first grade students in year 2017/2018 was 30.126 in total (14.609 of girls). All in all, 384 first form students had to be tested. This study was only observational and therefore a smaller number of respondents were selected.

The school was randomly selected from primary schools in Lithuania. The study took place in 2017 from September to November in four Lithuanian general education schools that had primary education and primary education classes. The time and place of the study, with the consent of the parents, were agreed upon in advance with the school administration. The study involved 1st grade students $(N=93), 45$ of which were girls and 48 were boys. Mean weight, height for girls were $24.3 \pm 9(\mathrm{~kg}), 1.25 \pm 11(\mathrm{~m})$ and for boys $29.3 \pm$ $6(\mathrm{~kg}), 1.33 \pm 9(\mathrm{~m})$.

The testing of physical fitness. The students performed four physical fitness tests (PFT) during physical education lessons They performed the European Physical Fitness Test Battery (Eurofit) in the following test order: the long jump test to test explosive power of children's leg muscles; flexibility (sit and reach test) (Venckunas, Emeljanovas, Mieziené, \& Volbekiené, 2017); $3 \times 10 \mathrm{~m}$ speed shuttle run test - agility (Ivanovas \& Paškevičienė, 2003); medical (stuffed) $1 \mathrm{~kg}$ ball pushing from the chest test explosive power of the hands (Fjørtoft, Pedersen, Sigmundsson, \& Vereijken, 2011).

The evaluation of physical activity. Children's Physical Activity Questionnaire (Corder, van Sluijs, Wright, Whincup, Wareham, \& Ekelund, 2009) was used. It was also based on the Children's Leisure Activities Study Survey (CLASS) questionnaire, which included activities specific to young children, such as "playing in a playhouse." The original intent of the proxy-reported CLASS questionnaire for 6-7-year-olds was to assess type, frequency, and intensity of physical activity over a usual week.

Mathematical diagnostic progress tests. Mathematical Diagnostic Progress tests (MDPT) were prepared in accordance with the requirements of the General Mathematics Education Curriculum (approved by ISAK-2433 of 26 August 2008). Diagnostic progress tests are an objective way to measure the achievement of skills and abilities. MDPT is divided into two parts: the division of tasks by achievement levels; the division of tasks according to the content and fields of activity; the division of tasks according to cognitive skill groups. The assessment of all areas of activity is based on the levels of student achievement levels (unsatisfactory, satisfactory, basic, and advanced).

Distribution of mathematical learning achievements by curriculum content. Diagnostic tests of mathematics evaluate the students' knowledge, skills, subject and general skills of mathematics acquired in the first grade according to the five fields of mathematics education curriculum:

1) numbers and calculations;

2) phenomena, equations, inequalities;

3) geometry, measures and measurements;

4) statistics;

5) communication and general problem-solving strategies.

The learning achievements described in the General Programs in the fields of Geometry, Measures and Measurement are combined in the Diagnostic Assessment Program and described in one area of the curriculum content - Geometry, Measures and Measurements. It were 7 possible MDPT tasks.

Learning achievements of mathematics according to the groups' cognitive abilities. The tasks of the mathematical diagnostic tests are aimed at assessing the abilities of students according to three groups of cognitive abilities: mathematical knowledge and understanding, application of mathematics and higher thinking abilities.

Instructions for evaluating all mathematical diagnostic progress tests were developed to assess pupils 'achievement, helping to ensure a uniform assessment of all students' work. All fields of activity are based on student achievement levels (unsatisfactory, satisfactory, basic, and advanced).

Mathematical statistics. The arithmetic mean (x) and the average standard deviation (SD) were 
determined for comparison. Differences between different genders, age and physical fitness were estimated using one-factor dispersion analysis (ANOVA). The relationship between variables was calculated on the basis of the correlation coefficient of the Spearman correlation coefficient. Differences between different genders and physical activity were estimated using Mann-Whitney $U$ test. The following reliability levels were used for statistical outputs: $p>.05$ - insignificant; $p<.05-$ significant. All calculations were performed using MS Excel and SPSS programs.

\section{RESULTS}

Physical activity of 7-year-old children. Analysing the results of 7-year-old students' physical activity (PA), it turned out that both boys (95.87 MET / min / week) and girls (91.30 MET / $\mathrm{min} /$ week) were physically active in physical education lessons $(p>.05)$.

The analysis of PA types such as cycling to school and walking to school showed that there were no differences of gender according to MET. The higher number of boys (1095.65 MET/ $\mathrm{min}$ / week) was found to be of the average PA compared to the girls (657.39 MET, min / week). The statistically significant difference was found in the analysis of the MET average per boy (1191.52 MET / min / week) compared to the girls (785.86 MET, min / week, $p<.05$; Table 1).

Physical fitness of 7-year-old children. While analysing the results of 7-year-old students' (boys and girls) physical fitness (PF) tests, it turned out that the results of the long jump test ranged from $105.2 \mathrm{~cm}$ (girls) to $118.3 \mathrm{~cm}$ (boys), statistically significant differences were detected $(p<.05)$ (Table 2). The girls $(r=2.73 \mathrm{~m})$ performed worse than the boys $(3.35 \mathrm{~m})(p<.05)$ in the medical (stuffed) $1 \mathrm{~kg}$ ball pushing from the chest test. The best score of the girls' $3 \times 10 \mathrm{~m}$ speed shuttle run test was $9.55 \mathrm{~s}$, for boys it was $9.2 \mathrm{~s}$, the worst performance time for boys was $13.68 \mathrm{~s}$, for girls $13.54 \mathrm{~s}(p<.05)$. Comparing the results of boys' and girls' flexibility, there were no statistically significant differences $(p>.05)$ : the girls' flexibility was about $0.05 \mathrm{~cm}$, for boys $-1.6 \mathrm{~cm}$.

Statistically significant correlations were determined between the standing long jump test and $3 \times 10 \mathrm{~m}$ speed shuttle run test results $(r=-.939, p<.01)$; between the long jump and the medical (stuffed) $1 \mathrm{~kg}$ of ball pushing from the chest $(r=-.945, p<.01)$; between the long jump and the flexibility test - sit and reach $(r=.945$, $p<.01)$.

A strong correlation was identified between the results of $3 \times 10 \mathrm{~m}$ speed shuttle run test and the medical (stuffed) $1 \mathrm{~kg}$ ball pushing from the chest $(r=-.960, p<.01)$; between the $3 \times 10 \mathrm{~m}$ speed shuttle run test and flexibility test - sit and reach $(r=.949, p<.01)$. A strong correlation (Table 2) was also identified between the medical (stuffed) $1 \mathrm{~kg}$ ball pushing from the chest and flexibility test - sit and reach $(r=.942, p<.01)$. A statistically significant $(p<.05)$ strong $(r=.722)$ correlation was identified after conducting Spearman correlation analysis between physical activity and physical fitness. This shows that PA affects PF.

\begin{tabular}{|l|c|c|c|c|c|}
\hline \multicolumn{1}{|c|}{ Type of physical activity } & MET & 1 day/min & Days per week & MET (min/week) \\
\hline \multicolumn{5}{|c|}{ Boys } \\
\hline Physical Education lesson & 3.5 & 30 & 1 & 95.87 \\
\hline Cycling to school & 4 & 0 & 3 & 0.00 \\
\hline Walking to school & 3.3 & 0 & 4 & 0.00 \\
\hline Sport groups(medium FA) & 6 & 60 & 1 & 1095.65 \\
\hline & & \multicolumn{5}{|c|}{ On average for one boy } & $1191.52^{*}$ \\
\hline & 3.5 & 30 & 1 & 91.30 \\
\hline Physical Education lesson & 4 & 0.45 & 3 & 15.65 \\
\hline Cycling to school & 3.3 & 0.87 & 4 & 21.52 \\
\hline Walking to school & 6 & 60 & 1 & 657.39 \\
\hline Sport groups(medium FA) & & \multicolumn{5}{|c|}{ On average for one girl } & $785.86^{*}$ \\
\hline
\end{tabular}

Table 1. Determining physical activity levels using the MET method 


\begin{tabular}{|c|c|c|c|c|c|}
\hline \multirow{10}{*}{$\begin{array}{l}\text { Table 2. Comparison } \\
\text { of } 7 \text { - year-old boys' } \\
\text { and girls' indicators } \\
\text { of physical fitness }\end{array}$} & Test & Girls & Boys & $\begin{array}{c}\text { F criterion value; } \\
\text { p level }\end{array}$ & $\begin{array}{l}\text { Observed } \\
\text { Power }\end{array}$ \\
\hline & Long jump (cm) & $105.2(12.1)$ & $118.3(9.8)$ & $\begin{array}{c}28.017 \\
.000\end{array}$ & 1.000 \\
\hline & $\begin{array}{l}\text { Medical (stuffed) } 1 \mathrm{~kg} \text { ball } \\
\text { pushing from the chest (m) }\end{array}$ & $2.73(0.27)$ & $3.35(0.65)$ & $\begin{array}{l}73.460 \\
.000\end{array}$ & 1.000 \\
\hline & $3 \times 10 \mathrm{~m}$ speed shuttle run & $11.61(0.914)$ & $10.99(1.06)$ & $\begin{array}{c}21.082 \\
.000\end{array}$ & 0.996 \\
\hline & Sit and reach $(\mathrm{cm})$ & $0.05(7.09)$ & $-1.6(6.25)$ & $\begin{array}{c}3.475 \\
.064\end{array}$ & 0.459 \\
\hline & \multicolumn{5}{|c|}{ Relationships between students' physical fitness } \\
\hline & & Long jump (cm) & $\begin{array}{l}3 \times 10 \mathrm{~m} \text { speed } \\
\text { shuttle run }\end{array}$ & $\begin{array}{l}\text { Medical (stuffed) } \\
1 \mathrm{~kg} \text { ball pushing } \\
\text { from the chest }(\mathrm{m})\end{array}$ & $\begin{array}{l}\text { Sit and reach } \\
(\mathrm{cm})\end{array}$ \\
\hline & Long jump (cm) & 1 & & & \\
\hline & $\begin{array}{l}\text { Medical (stuffed) } 1 \mathrm{~kg} \text { ball } \\
\text { pusshing from the chest }(\mathrm{m})\end{array}$ & $-.939^{* *}$ & 1 & & \\
\hline & $3 \times 10 \mathrm{~m}$ speed shuttle run & $.945^{* *}$ & $-.960^{* *}$ & 1 & \\
\hline Note. $* * p<.01$ & Sit and reach $(\mathrm{cm})$ & $.945^{* *}$ & $-.949^{* *}$ & $.942^{* *}$ & 1 \\
\hline
\end{tabular}

Mathematical diagnostic progress tests. Analysing the results of 7-year-old students' (boys and girls) Mathematical Diagnostic Progress Tests (MDPT), it appeared that in the 7 possible MDPT tasks, both girls and boys demonstrated satisfactory levels, whereas the upper level (of 3 MDPT tasks) was not found (Figure 1). There were no significant gender differences $(p>.05)$.

Distribution of mathematical learning achievements according to curriculum content. When assessing students' learning achievements in terms of curriculum content, the numbers and calculations out of 9 presented the tasks were correct for girls $-7.86 \pm 1.07$, for boys $-7.75 \pm$ 1.37 , and differences between genders were not determined $(p>.05)$; phenomena, equations, inequalities - from the one presented was correctly performed by girls $-0.83 \pm 0.38$, by boys $-0.79 \pm$ 0.41 , and gender difference were not significant $(p>.05)$; Geometry, Measures and Measurements tasks correctly solved out of the four was as follows: girls $-3.72 \pm 0.51$, boys $-3.71 \pm 0.50$, difference between genders was insignificant $(p>$ $.05)$; statistics -1 task solved correctly: girls $0.33 \pm 0.48$, boys $-0.31 \pm 0.47$, the difference between genders was insignificant $(p>.05)$.
Figure 1. Distribution of Mathematical diagnostic progress test results

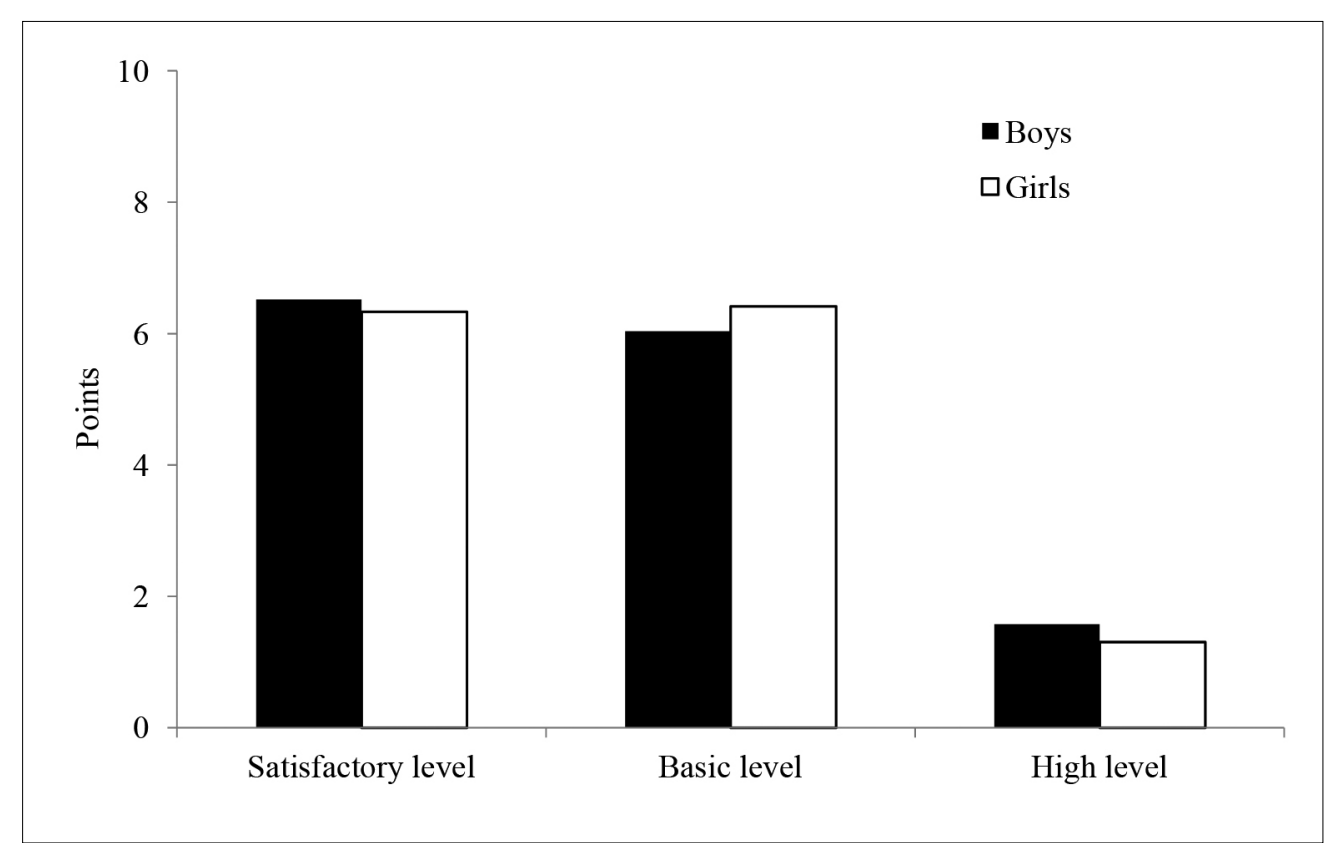


Figure 2. Distribution of mathematical learning achievements according to the curriculum content

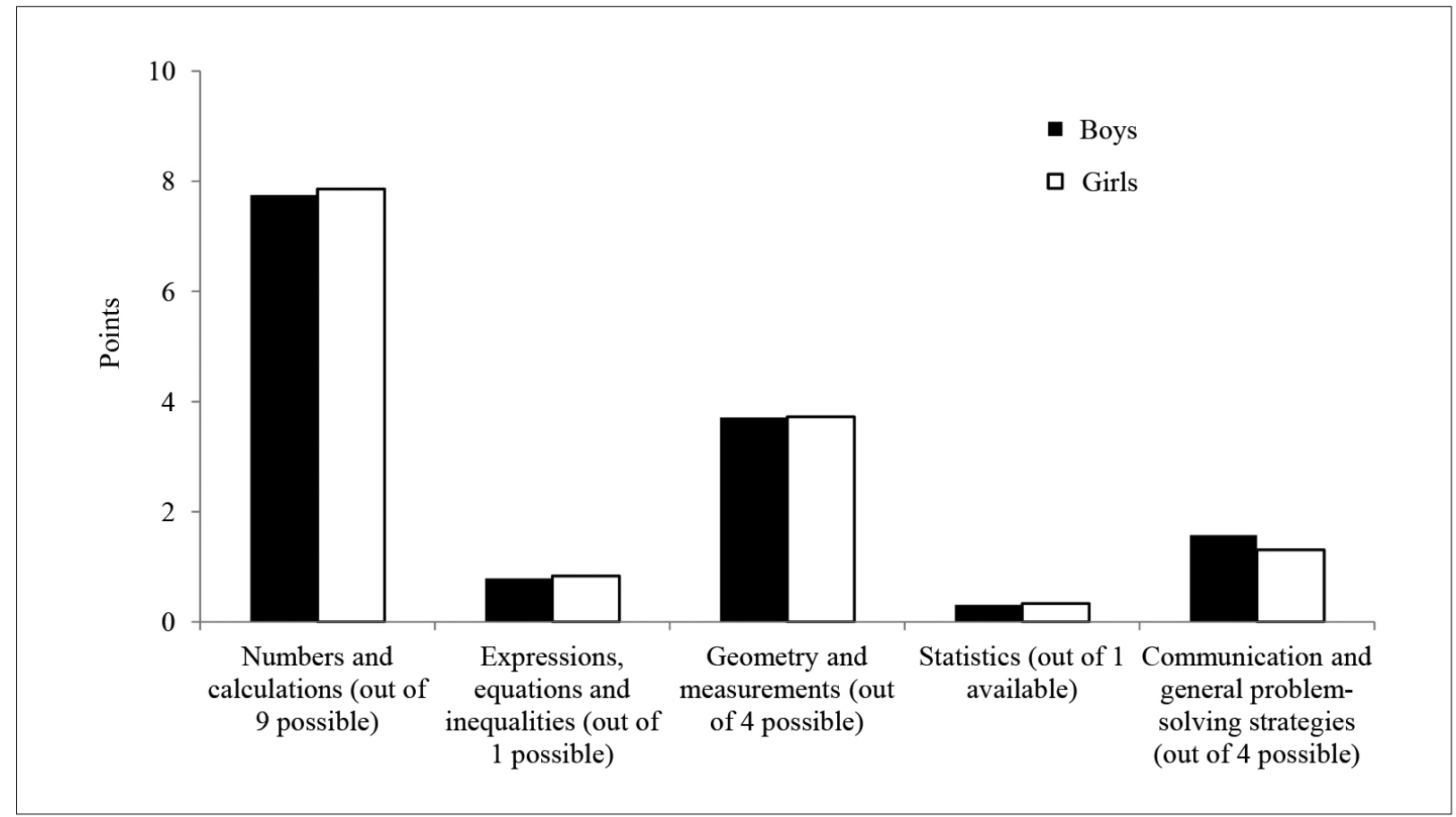

We suggest that this corresponds to the learning outcomes described in the general curriculum for boys and girls. However, communication and general problem-solving strategies of the four tasks presented correctly were: for girls $-1.31 \pm 0.69$, for boys $-1.58 \pm 0.96$, and the difference between the genders was significant $(p<.05)$ (Figure 2). This indicates that this area is the weakest and there is a need for improvement.

Learning achievements of mathematics according to the group's cognitive abilities. It was found that mathematical knowledge and understanding of the 6 tasks presented were correct for girls $5.53 \pm 0.56$, for boys $-5.58 \pm$ 0.67 , gender differences were not found $(p>.05)$ while assessing the achievements of students' mathematics learning in cognitive capacity groups; out of eight mathematics tasks presented correctly were solved: girls $-6.47 \pm 0.88$, boys $-6.25 \pm 1.36$, gender differences were not determined $(p>.05)$, and according to the higher thinking abilities of the four tasks presented, correctly were done: girls $2.06 \pm 1.19$, boys $-2.31 \pm 1.20$, no gender difference was established $(p>.05)$.

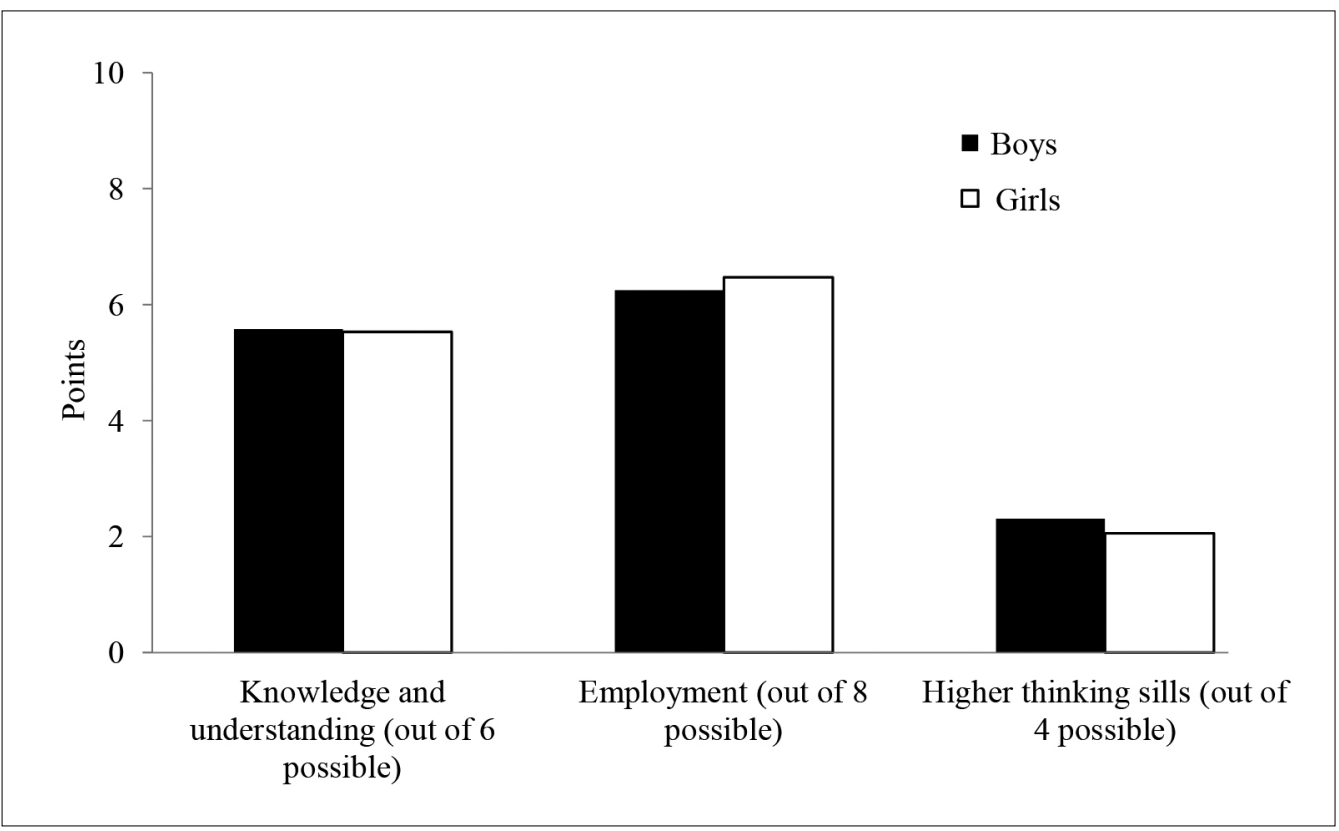

Figure 3. Learning achievements in mathematics according to cognitive capacity groups 


\section{DISCUSSION}

The findings of this study add evidence and detail to the proposition that an association exists between physical activity, physical fitness and academic achievements in primary school children. It should be noted that all 4 fitness tests had a positive, linear association with physical fitness tests and mathematics test scores.

Physical Activity. Over the last few decades, children's physical activity levels have changed dramatically. Outdoor physical play is increasingly being replaced by less physical indoor activities (Anderssen, Harro, \& Sardinha, 2006), 6-8-yearold children are increasingly being driven to school by car or bus instead of cycling or walking, and participation in organized sports is declining (Grund, Dilba, \& Forberger, 2000). A similar pattern of a substantial contribution from walking and a comparatively small contribution to overall physical activity from sport has also been reported in adults in England (Bélanger, Townsend, \& Foster, 2011) indicating that this pattern continues into adulthood. Active play was the largest contributor to overall physical activity in younger children but with increasing age walking took over. Such changes with age in the type of activity undertaken by children are not unexpected given their changing maturity across the age range of 5-15 years and their increasing independence, particularly given that some of the time spent walking may be for active travel purposes (excluding to/from school). The contribution from sport increased with age for both boys and girls, contributing the most among older boys (Allender, Cowburn, \& Foster, 2006). The main differences in our study between the activity profile of girls and boy were the contributions from sport, which made a smaller contribution among girls than boys (on average for one boy 1095.65 MET min/week, on average for one girl 785.86 MET min/week). At all ages, sport contributed a larger proportion to physical activity among boys than among girls. Few other studies have looked at the role of informal play, active travel and domestic activity in addition to structured sport and exercise, in the total physical activity of children (Telama et al., 2005) and yet this study shows that play in particular is an important contributor. Differences in the activity profile of boys and girls, particularly the role played by sport, may reflect gender differences in motivations for physical activity. Several studies have found that males are more motivated by competition than females (Vilhjalmsson \& Kristjansdottir, 2003). Vilhjalmsson and Kristjansdottir (2003) concluded, in a study of the gender differences in activity among Icelandic schoolchildren, that the difference in overall physical activity between boys and girls was entirely attributable to lower participation in sport among girls. Our study indicates that although the proportion of all activity achieved through sport differs between boys and girls. Therefore, still the question is how the frequency, intensity, and duration of physical activity in children affect their physical fitness and how decreasing levels of physical activity may be related to possible changes in physical fitness and to further health problems later in life, such as obesity, diabetes, osteoporosis, back pain, cardiovascular disease (Timpka, Petersson, \& Zhou, 2014), hypertension (Faselis, Doumas, \& Kokkinos, 2012) and cancer (Marshall \& Bouffard, 1997).

Physical Fitness. For investigating such relationships, reliable tests that can establish children's physical fitness in large population samples are needed. The optimal use of the analysis of the physical strength of each child allows predicting the extent and intensity of physical activity, with emphasis on relevant attributes.

Physical exercises can be used to strengthen the health and individual exercises that have a positive effect on their physical development by knowing the abilities of a particular child (Visagurskiene \& Grigonienè, 2016). Childhood is an important stage in which one can build fitness potential and develop lifestyle habits to maintain it (Venckunas et al., 2017). To this line, the recent prospective study has shown that physical fitness and fundamental movement skills developed in early adolescence predict total, moderate, and vigorous physical activity levels 6 years later (Jaakkola, Yli-Piipari, \& Huotari, 2016).

The article presents physical fitness of younger schoolchildren in Lithuania. PF tests are presented that are simple to use but reflect the physical activity of the students in the initial classes, hand muscle strength, motor skills, coordination, flexibility, and agility. Physical fitness tests were evaluated in accordance with Buliuolienė Daukšaitè, Klizas, Klizienè, and Cibulskas (2017), the reference tables for physical development and physical fitness were developed. The tables allowed classifying 
the students according to physical fitness levels. The explosive strength of the muscles of the primary school students has a satisfactory level of achievement (Buliuolienè et al., 2017). Our obtained results compared to the research done by Greek scientists showed that the result of the long jump of girls living in Greece is significantly better $(141 \pm 1.2 \mathrm{~cm})$ than that of girls studying in Lithuania, the results of boys are similar (132 \pm 0.2 cm) (Velikoek, Tsoukos, \& Bogdan, 2012).

Academic achievements. PA-related changes in children's brain function and cognition (e.g., attention, information processing, executive function, and memory) have been implicated as cornerstones for gains in academic performance (Donnelly et al., 2016). Coe, Peterson, Blair, Schutten, and Peddie (2013) found that high fitness levels are positively associated with academic achievement in school-aged youth. The findings of this study add evidence and detail to the proposition that an association exists between physical activity, physical fitness and mathematic achievement of the primary schoolchildren.

Nirio et al. (2014) found that academic achievement scores were positively related to fitness levels. Good cardio-respiratory and speed/ agility levels were associated with high academic achievement after controlling for confounders. Van Dusen et al. (2011) found that cardiovascular fitness was found to have the strongest direct associations with academic achievement, with a standardized mean difference effect size of .34 (.32-.35) for boys-math and .33 (.31-.35) for girls-math. The next largest associations (as measured by effect size and mean difference in TAKS score) were with curl-ups, followed by push-ups, sit and reach, and trunk-lift which registered the lowest effect size of .07 (95\% CI: .05-.08).

\section{CONCLUSION}

The findings of this study add evidence and detail to the proposition that an association exists between physical activity, physical fitness and academic achievement of the primary schoolchildren. It should be noted that all 4 fitness tests had a positive, linear association with physical fitness tests and mathematics test scores.

Acknowledgements. The research is supported by a research grant from the Lithuanian Research Council, Promotion of Students' Scientific Activities, sponsored by the European Union Structural Funds (09.3.3-LMT-K-712-03-0101).

\section{REFERENCES}

Allender, S., Cowburn, G., \& Foster, C. (2006). Understanding participation in sport and physical activity among children and adults: A review of qualitative studies. Health Education Research, 21, 826-835. https://doi.org/10.1093/her/cyl063

Anderssen, L., Harro, M., \& Sardinha, L. (2006). Physical activity and clustered cardiovascular risk in children: A cross-sectional study (The European Youth Heart Study). Lancet, 368, 299-304. https://doi. org/10.1016/S0140-6736(06)69075-2

Bélanger, M., Townsend, N., \& Foster, C. (2011). Agerelated differences in physical activity profiles of English adults. Preventive Medicine, 52, 247-249. https://doi. org/10.1016/j.ypmed.2011.02.008

Booth, M. Z., Curran, E. M., Frey, C. J., Gerard, J. M., Collet, B., \& Bartimole, J. (2014). Ethnic identity, gender, and adolescent attitude toward school: Adaptive perspectives in diverse settings. Mid-western educational researcher: Official publication of the Mid-Western. Educational Research Association, 26(2), 3-27.

Buliuolienè, L., Daukšaitė, L., Klizas, Š., Klizienè, I., \& Cibulskas, G. (2017). Kūno kultūra: mokytojo knyga 2 klasei. Kaunas: Šviesa.
Coe, D. P., Peterson, T., Blair, C., Schutten, M. C., \& Peddie, H. (2013). Physical fitness, academic achievement, and socioeconomic status in school-aged youth. Journal of School Health, 83(7), 500-507. https:// doi.org/10.1111/josh.12058

Corder, K., van Sluijs, E. M., Wright, A., Whincup, P., Wareham, N. J., \& Ekelund, U. (2009). Is it possible to assess free-living physical activity and energy expenditure in young people by self-report? The American Journal of Clinical Nutrition, 89(3), 862-870. https://doi.org/10.3945/ajcn.2008.26739

Diamond, A. (2013). Executive functions. Annual Review of Psychology, 64, 135-168. https://doi. org/10.1146/annurev-psych-113011-143750

Donnelly, J. E., Hillman, C. H., Castelli, D., Etnier, J. L., Lee, S., Tomporowski, P., ... Szabo-Reed, A. N. (2016). Physical Activity, Fitness, Cognitive Function, and Academic Achievement in Children: A Systematic Review. Medicine and Science in Sports and Exercise, 48(6), 1197-1222. https://doi.org/10.1249/ MSS.0000000000000901

Erickson, K. I., Hillman, C. H., \& Kramer, A. F. (2015). Physical activity, brain, and cognition. Current Opinion 
in Behavioral Sciences, 4(0), 27-32. doi: 10.1016/j. cobeha.2015.01.005

Faselis, C., Doumas, M., \& Kokkinos, J. P. (2012). Exercise capacity and progression from prehypertension to hypertension. Hypertension, 60, 333-338. https://doi. org/10.1161/HYPERTENSIONAHA.112.196493

Fjørtoft, I., Pedersen, A. V., Sigmundsson, H., \& Vereijken, B. (2011). Measuring physical fitness in children who are 5 to 12 years old with a test battery that is functional and easy to administer. Physical Therapy, 91(7), 1087-1095. https://doi.org/10.2466/10. PMS.121c $24 \times 2$

Grund, A., Dilba, B., \& Forberger, K. (2000). Relationships between physical activity, physical fitness, muscle strength and nutritional state in 5- to 11-year-old children. European Journal of Applied Physiology, 82, 425-438. https://doi.org/10.1007/s004210000197

Ivanovas, P., \& Paškevičienè, L. (2003). Kūno kultūros pamoku turinys (pirmoji klasé). Šiaurès Lietuva.

Jaakkola, T., Yli-Piipari, S., \& Huotari, P. (2016). Fundamental movement skills and physical fitness as predictors of physical activity: A 6-year follow-up study. Scandinavian Journal of Medicine \& Science in Sports, 26, 74-81. doi: 10.1111/sms. 12407

Janssen, I., \& LeBlanc, A. G. (2010). Review Systematic review of the health benefits of physical activity and fitness in school-aged children and youth. The International Journal of Behavioral Nutrition and Physical Activity, 7(40), 1-16. https://doi.org/10.1186/1479-5868-7-40

Marshall, J. D., \& Bouffard, M. (1997). The effects of quality daily physical education on movement competency in obese versus no obese children. Adapted Physical Activity Quarterly: APAQ, 14, 222-237.

Nirio, C. T., Vizcaino, V. M., Guijarro, M. J. P., Prieto, J. C. G. P., Palencia, N. M. A., \& Lopez M. S. (2014). Physical fitness, obesity, and academic achievement in schoolchildren. The Journal of Pediatrics, 165(1), 104-109.

Powell, E., Woodfield, L. A., \& Nevill, A. M. (2016). Increasing physical activity levels in primary school physical education: The SHARP Principles Model. Preventive Medicine Reports, 3, 7-13.

Rowlands, A. V., Ingledew, D., \& Eston, R. (2000). The effect of type of physical activity measure on the relationship between body fatness and habitual physical activity in children: A meta-analysis. Annals of Human Biology, 27, 479-497.

Syväoja, H., Kantomaa, M. T., Ahonen, T., Hakonen, H., Kankaanpää, A., \& Tammelin, T. H. (2013). Physical activity, sedentary behavior, and academic performance in Finnish children. Medicine and Science in Sports and Exercise, 45(11), 2098-2104.

Telama, R., Yang, X., Viikari, J., Välimäki, I., Wanne, O., \& Raitakari, O. (2005). Physical activity from childhood to adulthood: A 21-year tracking study. American Journal of Preventive Medicine, 28, 267-273. https:// doi.org/10.1016/j.amepre.2004.12.003

Timpka, S., Petersson, I. F., \& Zhou, C. (2014). Muscle strength in adolescent men and risk of cardiovascular disease events and mortality in middle age: A prospective cohort study. BMC Medicine, 12, 62-68.

Tomporowski, P. D., Davis, C. L., Miller, P. H., \& Naglieri, J. A. (2008). Exercise and children's intelligence, cognition, and academic achievement. Educational Psychology Review, 20(2), 111-131. https:// dx.doi.org/10.1007\%2Fs10648-007-9057-0

Van Dusen, D. P., Kelder, S. H., Kohl, H. W., Ranjit, N., \& Perry, C. L. (2011). Associations of physical fitness and academic performance among schoolchildren. Journal of School Health, 81(12), 733-740.

Velikoek, P., Tsoukos, A., \& Bogdanis, G. C. (2012). Determinants of standing long jump performance in 9-12 years old children. Serbian Journal of Sports Science, 6(4), 147-155.

Venckunas, T., Emeljanovas, A., Mieziene, B., \& Volbekiene, V. (2017). Secular trends in physical fitness and body size in Lithuanian children and adolescents between 1992 and 2012. Journal of Epidemiology and Community Health, 71(2), 181-187. https://doi. org/10.1136/jech-2016-207307

Vilhjalmsson, R., \& Kristjansdottir, G. (2003). Gender differences in physical activity in older children and adolescents: The central role of organized sport. Social Science and Medicine, 56, 363-374. http://dx.doi. org/10.1016/S0277-9536(02)00042-4

Visagurskienè, K., \& Grigonienè, J. (2016). Ikimokyklinio ir pradinio mokyklinio amžiaus vaiku fiziniu ypatybiu tetstavimas ir ugdymas. Metodine priemone pedagogams. Kaunas: LSU. 